\title{
The role of competitive advantage in mediating the effect of promotional strategy on marketing performance
}

\author{
Ni Nyoman Kerti Yasa ${ }^{a}$, I G. A. Ketut Giantaria ${ }^{a}$ Made Setini $^{* *}$ and Putu Laksmita Dewi Rahma- \\ yantic $^{\mathrm{c}}$
}

${ }^{a}$ Lecturer at Faculty of Economics and Business, Udayana University, Bali, Indonesia

${ }^{b}$ Student at Doctoral Program, Faculty of Economics and Business, Udayana University, Bali, Indonesia ${ }^{c}$ Student at Magister Management Program, Faculty of Economics and Business, Udayana University, Bali, Indonesia

\section{H R O N I C L E}

\section{Article history:}

Received: February 10, 2020

Received in revised format:

March 202020

Accepted: April 17, 2020

Available online:

April 17, 2020

Keywords:

Promotional strategy

Competitive advantage

Marketing performance

\section{Introduction}

In the increasingly tight competition, most businesses implement several business strategies to maintain their existence and continuity. The Small and Medium Enterprises (SMEs) operating in the Tenun Ikat Craft Industry in Bali Indonesia, in fact, have already implemented many business strategies, among others the innovation strategy, differentiation strategy, service strategy, and cooperative strategy (Yasa et al., 2013). The studies revealed that four business strategies had positive and significant effects on the competitive advantage achievement. However, despite the business strategies the Tenun Ikat SME have implemented, the results are still not desirable yet. This is seen from the annual sales data, which measures the performance of the SME, that does not show an increasing year to year trend. There is a need for other business strategies to improve the competitive advantage of the SME in order to increase their marketing performance. Another business strategy which has not been reviewed is promotional strategy. Promotional strategy is needed to introduce the product more intensively so that the market is more aware, more knowledgeable of the product innovation conducted, and to strengthen the brand (Chung et al., 2019), for example by providing price discounts (Manzur et al., 2013; Rothlin, 2013; Kumar et al., 2016) or other promotional activities, such as through social media (Akar \& Topcu, 2011; Karpinski et al., 2013; Yasa et al., 2020). By using the promotional strategy, it will be easier for the Tenun Ikat SME to be memorized by the market, be more popular, and influence their business image or reputation. If promotional strategy has been implemented properly and intensively, the competitive advantage resulted is expected to be higher and this will result in the increase in marketing performance. Therefore, to achieve

* Corresponding author. Tel.: +62 8155789999

E-mail address: Gitan4nd4@gmail.com (M. Setini)

(C) 2020 by the authors; licensee Growing Science, Canada doi: $10.5267 /$ j.msl.2020.4.024 
a competitive advantage in terms of brand power, brand popularity, and product image, the Tenun Ikat SME must implement promotional strategies which would eventually increase the marketing performance of their business. If a SME has a competitive advantage, there will surely be a positive impact on the performance of the company (Song et al., 2013; Anvar et al., 2018; Dominguez \& Mayrhofer, 2018). Based on the business issues faced by the Tenun Ikat industry in Bali Indonesia, and as there are no previous studies that have reviewed promotional strategy complemented with empirical results related to the existing issue, the motivations to conduct this research are: 1) to review the existing business issues; 2) to develop the literature by considering the promotional strategies that have been conducted, among others sales promotion, advertisement and social media promotion such as through Facebook, Line, and Instagram, so that competitive advantage can be achieved and this will result in the increase in the marketing performance of the SME. Thus, the aim of this research is to explain the influence of promotional strategy on competitive advantage and its impact on the increase in marketing performance of the Tenun Ikat Industry in Bali Indonesia.

\section{Research conceptual framework and research hypothesis}

\subsection{Research Conceptual Framework}

Marketing performance is among the measures of firm performance. This performance can be measured using the level of annual sales, market share growth, and operational profit. The marketing performance achievement is determined by many factors, and among them is the business strategy implemented. An important business strategy that is able to increase the total sales is promotional strategy. In addition, promotional strategy is also able to strengthen the competitiveness of the firm because by conducting promotions, the product's brand becomes more popular, and is always remembered by the market. In other words, it has a positive influence on the marketing performance achievement. Fig. 1 shows the proposed study.

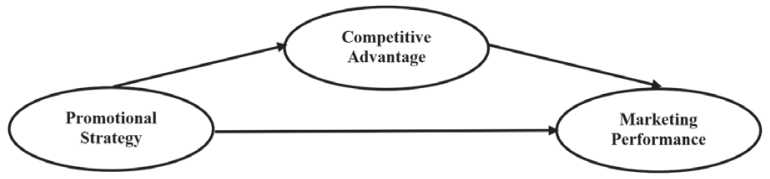

Fig. 1. Research Conceptual Framework

\subsection{Research Hypothesis}

Based on the available conceptual framework, the research hypotheses are formulated as follows.

$\mathrm{H}_{1}$ : Promotional strategy has a positive and significant influence on marketing performance.

$\mathrm{H}_{2}$ : Promotional strategy has a positive and significant influence on competitive advantage.

$\mathrm{H}_{3}$ : Competitive advantage has a positive and significant influence on marketing performance.

$\mathrm{H}_{4}$ : Competitive advantage is able to significantly mediate the influence of promotional strategy on marketing performance.

\section{Research method}

This research is conducted on the SMEs in the Tenun Ikat Industry in all regencies/cities in Bali Indonesia Province, namely: Denpasar City, Gianyar Regency, Bangli Regency, Klungkung Regency, Karangasem Regency, Buleleng Regency, Jembrana Regency, Badung Regency, and Tabanan Regency. In this research, there are three types of variables being examined. These variables are: 1) the exogenous variable: promotional strategy $\left.\left(\mathrm{X}_{1}\right) ; 2\right)$ the intervening variable: Competitive advantage $\left(\mathrm{Y}_{1}\right)$; and 3) the Endogenous Variable: Marketing Performance $\left(\mathrm{Y}_{2}\right)$. The population in this research covers all the SMEs operating in the Tenun Ikat Industry sector in Bali Indonesia Province. The sample size in this research is 100 Tenun Ikat SME in Bali Indonesia Province. The indicators of the promotional strategy variable, competitive advantage, and marketing performance variables are measured through the perspective of the owners or managers of the Tenun Ikat SME as the ones who formulate the strategy, using the five level Likert Scale, in which strongly disagree $=1$ to strongly agree $=5$. The validity and reliability of the instruments used are examined to ensure that the instruments measure what it is meant to measure and to determine the consistency of responses provided by respondents. The instrument validity test is conducted using Pearson's Product Moment Correlation technique with a minimum limit $\mathrm{t}=0.3$ (Sugiyono, 2018: 150). The instrument reliability test is conducted by calculating the Cronbach's Alpha reliability coefficient with a minimum limit alpha coefficient of $>0.6$ (Sekaran, 2003: 312). Both tests utilize the SPSS computer application, and the data analysis is based on (SEM) Analysis.

\section{Results and discussion}

\subsection{Results and hypotheses testing}

Table 1 displays the direct influence hypothesis test results. The SEM analysis results regarding the influence of Promotional Strategy (X) on Marketing Performance (Y2) shows a direct influence path coefficient of 0. 45(P-value $=0.000)$. Thus, the hypothesis in which "promotional strategy (X) has a direct influence on the marketing performance of SME (Y2)" is accepted. A positive path coefficient (0.45) shows that the relationship between the two variables is positive. In other words, the better promotional strategy $(\mathrm{X})$, the higher the marketing performance (Y2). Conversely, the lower promotional strategy (X), the lower the marketing performance (Y2). From the SEM analysis results, the influence of Promotional Strategy (X) on Competitive Advantage (Y1) attained a direct influence path coefficient of 0.70 and a $p$-value of 0.000 . Since the $p$-value is $<5 \%$, the hypothesis "Promotional Strategy (X) has a direct influence on Competitive Advantage (Y1)" is accepted. 
Table 1

The Direct Influence Hypothesis Test Results

\begin{tabular}{ccc}
\hline Independent Variable & Dependent Variable & Path Coefficient \\
\hline Promotional Strategy (X) & Marketing Performance (Y2) & 0.45 \\
Promotional Strategy (X) & Competitive Advantage (Y1) & 0.000 \\
Competitive Advantage (Y1) & Marketing Performance (Y2) & 0.70 \\
\hline
\end{tabular}

A positive path coefficient (0.70) shows that the relationship between the two variables is positive, and this means that with a better promotional strategy $(\mathrm{X})$, the company will have a greater competitive advantage (Y1). From the SEM analysis results, the influence of competitive advantage (Y1) on marketing performance (Y2) attained a direct influence path coefficient of 0. 51 and a p-value of 0,000 . Since the p-value is $<5 \%$, the hypothesis "Competitive Advantage (Y1) has a direct influence on Marketing Performance (Y2)" is accepted. A positive path coefficient (0.51) shows that the relationship between the two variables is positive, and this means that with a higher competitive advantage (Y1), there will be a higher level of Marketing Performance (Y2), vice versa. From the SEM analysis results, the influence of the Promotional Strategy variable (X) on Marketing Performance (Y2) through Competitive Advantage (Y1) attained an indirect influence path coefficient of 0.357 and a p-value of 0.000 . Since the p-value is $<5 \%$, the hypothesis "Promotional Strategy has an indirect influence on the Marketing Performance (Y2) through Competitive Advantage (Y1)" is accepted. The positive path coefficient (0.357) shows that the relationship between the two variables through competitive advantage is positive. This means that with a better promotional strategy (X) and by achieving a greater competitive advantage (Y1), the marketing performance (Y2) will be higher. Conversely, the worse the promotional strategy $(\mathrm{X})$ while having a competitive advantage, the lower the marketing performance (Y2).

\subsection{Discussion}

From the validity and reliability calculation results, each indicator is known to be capable of measuring the variable and concept it measures, and the concepts are independent between one and others. By performing the confirmatory factor analysis (goodness of fit test and factor weightage significance test), evidence shows that the observed variables are able to reflect the factors being analyzed. By performing the overall goodness of fit test and the regression weight causality test, evidence shows that the model has a good overall fit and the causality relationship developed is examinable.

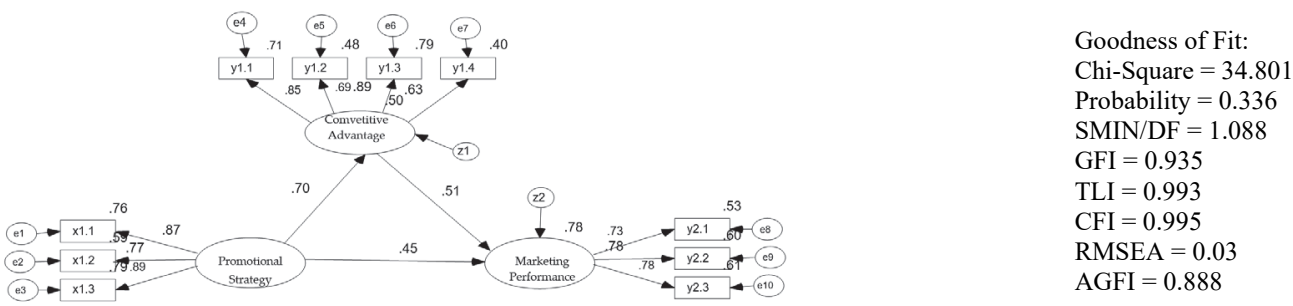

Fig. 2. The results of testing hypotheses

Based on Table 1, the promotional strategy variable is known to have a significant influence on the marketing performance of SME operating in the Tenun Ikat sector. This result is proven by the p-value of 0.043 which is smaller than 0.05 . There is a positive relationship between the promotional strategy variable and the marketing performance variable of the Tenun Ikat SME shown by an inner weight value of 0.45 . This result means the better promotional strategy, the higher the marketing performance of the SME in the Tenun Ikat industry sector in Bali Indonesia. In this research, the indicators of promotional strategy, which is formed by the variable indicators of advertisement activities, price discount, and promotion through social media, played an important role in increasing the performance of the firms in Indonesia Tenun Ikat industry. This result is in line with the conditions faced by the SME in the Tenun Ikat industry in Bali Indonesia. Promotional strategy would lead to the increase in marketing performance of the Tenun Ikat SME in Bali Indonesia. This is consistent with the research results attained by Quaye et al. (2017); Saju (2018); and Sam (2018). From Table 1, the promotional strategy variable is known to have a significant influence on the competitive advantage of SME in the Tenun Ikat industry sector. This is proven by a pvalue of 0.016 which is lower than 0.05 . There is a positive relationship between the promotional strategy variable and competitive advantage variable of the SME in the Tenun Ikat Industry in Bali Indonesia which is shown by an inner weight value of 0.70 . This result can be interpreted as the higher promotional strategy, the greater the competitive advantage of the Tenun Ikat industry sector in Bali Indonesia. In this research, the indicators of promotional strategy, which is formed by the variable indicators of advertisement, price discount, and promotion through social media, played an important role in increasing the competitive advantage of SME in the Tenun Ikat industry in Bali Indonesia. This research result is in line with the conditions faced by the Tenun Ikat SME in Bali Indonesia. The promotional strategy has improved the competitive advantage of Tenun Ikat SME in Bali Indonesia. From Table 1, the competitive advantage variable is known to have a significant influence on the marketing performance of Tenun Ikat SME in Bali Indonesia. This is proven by a p-value of 0.020 which is smaller than 0 . 05. There is a positive relationship between the competitive advantage variable and the marketing performance variable of Tenun Ikat SME in Bali Indonesia which is shown by an inner weight value of 0.51 . This result can be interpreted as the greater the competitive advantage, the higher the marketing performance of the Tenun Ikat SME in Bali Indonesia. In this research, the indicators of the competitive advantage variable, which is formed by the variable indicators of brand advantage, 
image advantage, and price advantage, have played an important role in increasing the marketing performance of the Tenun Ikat SME in Bali Indonesia. The results are in line with the conditions faced by the SME in the Tenun Ikat Industry sector in Bali Indonesia. Competitive advantage increases the marketing performance of the Tenun Ikat SME in Bali Indonesia. This is consistent with the research results attained by Sigalas and Pekka (2013). The hypothesis test regarding the role of competitive advantage in mediating the influence of promotional strategy on the marketing performance of the SME in the Tenun Ikat Industry sector in Bali Indonesia was conducted using the SEM analysis for the direct and indirect influence. The results have shown that the influence of promotional strategy on marketing performance is 0.45 , while the influence of promotional strategy on marketing performance through competitive advantage is 0.357 . Thus, competitive advantage has played a role as the partial mediator in the influence of promotional strategy on the marketing performance of the SME in the Tenun Ikat industry sector in Bali Indonesia. This means that promotional strategy positively stimulates the SME in acquiring a competitive advantage, which leads to the increase in marketing performance of the Tenun Ikat SME. This is consistent with the research results attained by Ainin et al. (2015); Quaye et al. (2017); and Saju (2018).

\section{Research implication and limitation}

As discussed in the analysis and discussion, this research has theoretically revealed the relationship between the latent variables of promotional strategy, competitive advantage, and marketing performance. This research also contributes ideas for the business practitioners or entrepreneurs of the Tenun Ikat SME in Bali Indonesia. The idea meant is for the SMEs to always maintain and strengthen the competitive advantage of their firms by conducting intensive promotional strategies in order to increase the marketing performance of the SME. Several limitations were also found in this research and some of the notable causes are as follows. 1) The respondents in this research are the managers or the entrepreneurs of the Tenun Ikat SME, thus the research results cannot be used for generalization purposes. 2) The mediating variable studied is the competitive advantage variable, which in this research has a role as the partial mediator in the influence of promotional strategy on marketing performance. Thus, for future studies there is a need to consider other mediating variables, such as company image and / or WOM because both of these variables can be used to conduct an intensive promotional strategy.

\section{References}

Ainin, S., Parveen, F., Moghavvemi, S., Jaafar, N. I., \& Shuib, N. L. M. (2015). Factors influencing the use of social media by SMEs and its performance outcomes. Industrial Management \& Data Systems.

Akar, E., \& Topçu, B. (2011). An examination of the factors influencing consumers' attitudes toward social media marketing. Journal of Internet Commerce, 10(1), 35-67.

Anwar, M., Rehman, A. U., \& Shah, S. Z. A. (2018). Networking and new venture's performance: Mediating role of competitive advantage. International Journal of Emerging Markets, 13(5), 998-1025

Chung, J. E., Jin, B., Jeong, S. W., \& Yang, H. (2019). NIE-based SME brand building in foreign markets: an exploratory study. Journal of Product \& Brand Management, 28(1), 63 - 79.

Dominguez, N., \& Mayrhofer, U. (2018). How can promotion agencies impact SME internationalisation? The case of the French company SLAT. Key Success Factors of SME Internationalisation: A Cross-Country Perspective, 121.

Jose, S. (2018). Strategic use of digital promotion strategies among female emigrant entrepreneurs in UAE. International Journal of Emerging Markets.

Quaye, D. M., Sekyere, K. N., \& Acheampong, G. (2017). Export promotion programmes and export performance. Review of International Business and Strategy.

Karpinski, A. C., Kirschner, P. A., Ozer, I., Mellott, J. A., \& Ochwo, P. (2013). An exploration of social networking site use, multitasking, and academic performance among United States and European university students. Computers in Human Behavior, 29(3), 1182-1192.

Kumar, A., Adlakha, A., \& Mukherjee, K. (2016). Modeling of product sales promotion and price discounting strategy using fuzzy logic in a retail organization. Industrial Management \& Data Systems, 116 (8), pp.1418 - 1444

Manzur, E., Olavarrieta, S., Hidalgo-Campos, P., \& Farías, P. (2014). Store price promotion strategies: An empirical study from Chile. Academia Revista Latinoamericana de Administración, 26(3), 356 - 372.

Quaye, D. M., Sekyere, K. N., \& Acheampong, G. (2017). Export promotion programmes and export performance. Review of International Business and Strategy.

Röthlin, F. (2013). Managerial strategies to reorient hospitals towards health promotion. Journal of Health Organization and Management, $27(6), 747-761$.

Sigalas, C., \& Economou, V. P. (2013). Revisiting the concept of competitive advantage. Journal of Strategy and Management, 6(1), 6180.

Sekaran, U. (2003). Research Methods For Business. New York: John Willey and Sons, Inc.

Sugiyono. (2018). Business Research Methods. Bandung: CV. Alfabeta

Song, X. M., \& Parry, M. E. (1997). A cross-national comparative study of new product development processes: Japan and the United States. Journal of marketing, 61(2), 1-18.

Yasa Kerti, N. N., Abdullah, J., Sukaatmadja, P. G., Kembar, S., \& Marhaeni, A. A. N. (2013). SME performance improvement and its effect on the poverty reduction in Bali. International Jurnal of Business Management Invention, 2(4), 01-12.

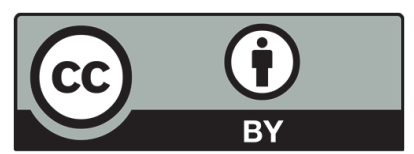

(C) 2020 by the authors; licensee Growing Science, Canada. This is an open access article distributed under the terms and conditions of the Creative Commons Attribution (CC-BY) license (http://creativecommons.org/licenses/by/4.0/). 